\title{
Editorial
}

\section{Geomorphology and Environmental Management of the Yellow River Source Zone}

\author{
BRIERLEY Gary ${ }^{1 *}$, LI Xi-lai ${ }^{2}$ \\ 1 School of Environment, University of Auckland, Private Bag 92019, Auckland, New Zealand \\ 2 College of Agriculture and Animal Husbandry, Qinghai University, Xining 810o16, China \\ *Corresponding author, e-mail: g.brierley@auckland.ac.nz
}

(C) Science Press and Institute of Mountain Hazards and Environment, CAS and Springer-Verlag Berlin Heidelberg 2013

Geologic, climatic and anthropogenic factors have fashioned the distinctive landscapes and ecosystems of the Yellow River source zone (Brierley and Huang 2013; Figure 1). Located at the north-east corner of the Qinghai-Tibetan Plateau (QTP), at elevations between 2500 and $4500 \mathrm{~m}$, this area has an arid/semi-arid climate. Many of these landscapes retain a significant imprint from Quaternary environmental changes. This mix of factors has induced marked variability in vegetation patterns and land use potential across this vast area, where land use practices have maintained grazing adapted ecosystems for several thousand years (Miehe et al. 2009). Despite the low population density, development pressures and climate change present significant threats to ecosystem values (e.g. Liu et al. 2012; Shapiro 2012). In recent decades, grassland and wetland degradation, alongside desertification, have placed significant stress upon land and water resources and biodiversity (including various iconic and endemic species, many of which are threatened or endangered). A sustainability focus recognizes that the costs of prevention of environmental degradation are significantly less than the costs of repair (if indeed repair is realistically achievable). Effective approaches to environmental protection and rehabilitation of rivers, wetlands and grasslands build upon a landscape platform, recognizing inherent links between geodiversity

Received: 15 June 2013

Accepted: 5 July 2013 and biodiversity (Blue et al. 2013; Li et al. 2012).

The Yellow River originates from the Bayankala Mountains atop the Qinghai-Tibetan Plateau of Qinghai Province, from which it flows through eight provinces and autonomous regions before emptying into the Bohai Sea north of the Shandong Peninsula. With a length of over 5400 $\mathrm{km}$, it is the second longest river in China and the tenth longest in the world. The basin contains approximately $9 \%$ of China's population and $17 \%$ of its agricultural area (Pietz and Giordano 2009). From its source at an elevation of around $4600 \mathrm{~m}$, the upper Yellow River flows through a series of deep gorges and basins atop the QTP (Nicoll et al. 2013). Alluvial reaches in wide and shallow valleys with gentle valley slopes are characterized by a wide range of river types, including anabranching, anastomosing, braided and meandering reaches (see Figure 1; Blue et al. 2013; Li et al. 2013; Yu et al. 2013). Upstream from Hekouzhen in Inner Mongolia, the upper Yellow River contributes around $200 \times 10^{8} \mathrm{~m}^{3}$ per year (about $56 \%$ of the total annual runoff of the basin). However, the upper Yellow River has a low sediment yield, generating about $1 \times 10^{8} \mathrm{t}$ suspended sediment per year (less than $10 \%$ of the annual suspended sediment load of the whole river basin) (Wang et al. 2007). Hence, while the source zone generates the largest portion of the total flow of the Yellow River, the majority of sediment is generated from the Loess Plateau in the middle reaches of its basin. Unlike the middle and lower reaches, which are 
subjected to major flow regulation, the Upper Yellow River is free-flowing in the most part.

This special issue presents an overview of various landscape-related environmental problems in the source zone of the Yellow River. Aiken and Brierley (2013) show how tectonic factors have fashioned geomorphic variability of river systems across the eastern margin of the QTP. Hillslope instability in the region has been markedly impacted by alterations to vegetation cover and infrastructure development (see Figure 1d). Hu et al. (2013) assess the prospective effectiveness of shrub revegetation programmes in efforts to reduce shallow landslide activity on loess hillslopes. Concerns for soil protection and soil erosion management are integral components of grassland and wetland management in the region. Vulnerability varies markedly in relation to elevation and climatic factors. Li et al. (2013) present an overview of controls upon grassland degradation in the region, and associated options for management. Finally, two papers by Gao et al. (2013 a, b) develop an approach to classification of alpine wetlands in the region, and consider approaches to assess their degradation and recovery prospects.

To date, scientific understandings of environmental issues in the source zone of the Yellow River remain fragmented, with relatively little intellectual cross over among fields such as geomorphology, terrestrial and aquatic ecology, hydrology (water resources), climatology and human ecology (Brierley 2010). More importantly, discipline-bound framings seldom extend across to meaningful incorporation of socio-economic and cultural associations, and local knowledge. The lack of coherent landscape-scale analyses of grassland, wetland and river ecosystems limits prospects for effective management of cumulative impacts that fashion environmental futures. Emerging technological developments present enormous opportunities to expand research initiatives in this area. Comparative and place-based research at the local to regional scale is required to relate fieldbased observations and measurements to laboratory experimental procedures and remotely sensed applications. Ultimately, it is the management of activities on-the-ground that will determine environmental outcomes. Appropriately contextualized understandings are required, rather than 'parachuting in' external perspectives or frameworks (see Brierley et al. 2013). Systemsbased overviews of pressures and threats are required to provide a platform for holistic thinking about cumulative impacts, enabling foresighting and scenario-setting exercises to appraise prospective responses to climate/land use change and management applications. Particular regard must be given to identification of biotic and abiotic threshold conditions beyond which prospects for rehabilitation are diminished (or costs become prohibitive). In addition, long term experimental and monitoring stations and demonstration sites are required to assess the effectiveness of management options.

Prospects for the Upper Yellow River basin are far from a 'doom and gloom' situation. Regional water resources remain plentiful and are an exceptionally valuable asset. Climate change will present new opportunities for land use developments. In an age of increasing concern for food security, there are significant prospects to expand organic farming techniques that build upon traditional lifestyles. Tourism numbers are booming as infrastructure developments create increasing opportunities for visitors to experience the stunning landscapes and ecosystems of this region. One thing is clear: the pace of change in this area ensures that it will be a very different place in a matter of years, rather than generations. Hopefully, the papers in this special issue will support efforts to protect environmental values of this remarkable place, such that these values will remain an integral component of future developments in the region.

\section{Acknowledgements}

The development of these papers was greatly assisted by discussions at workshops held at the IAHR conference at Tsinghua University (2011) and Education NZ sponsored workshops held at the Chinese Academy of Sciences (Beijing) and at Qinghai University (Xining) in 2012 (NZ-China Tripartite Fund). These collaborations form part of the environmental arm of the Three Brothers (Plus) agreement, in which researchers at The University of Auckland and the Chinese Academy of Sciences work alongside colleagues at Tsinghua University to support research developments at Qinghai 
University. Grants awarded through the International Science \& Technology Cooperation Program of China (2011DFG93160, 2011DFA20820) supported this research. Gary Brierley gratefully acknowledges support from a

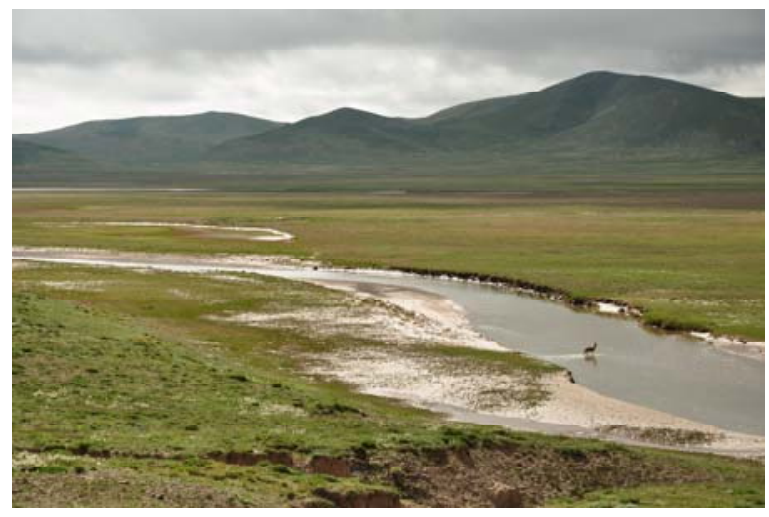

a) Tributary of the Upper Yellow River near Maduo

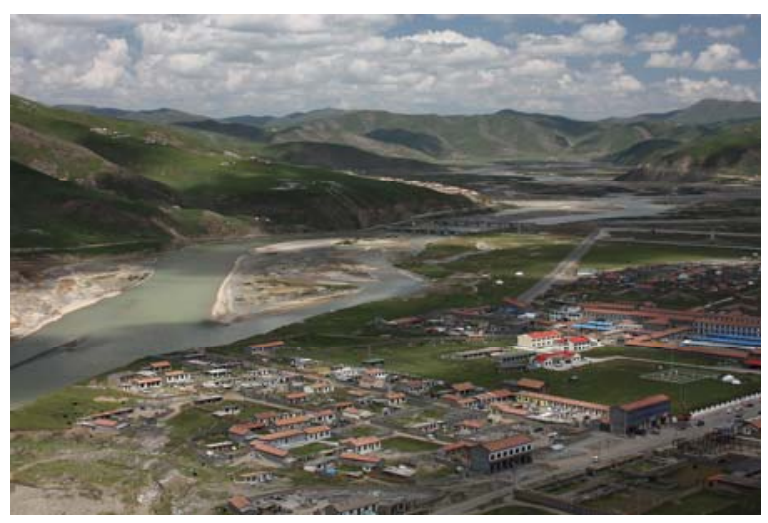

c) Upper Yellow River at Dari

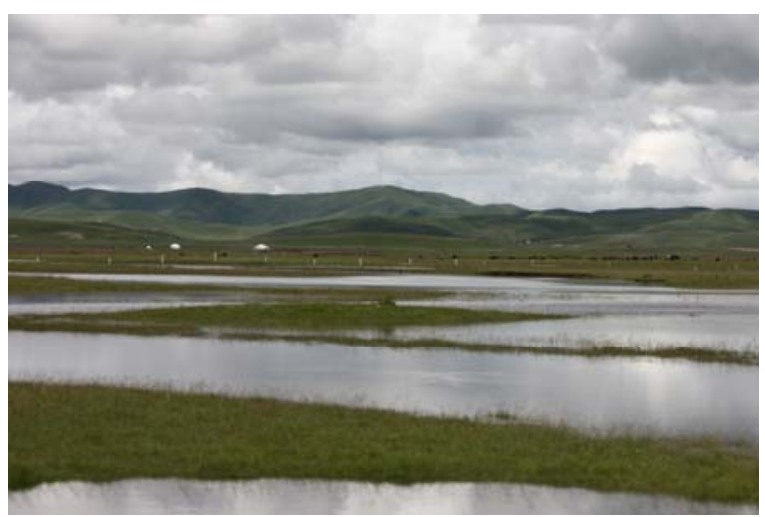

e) Wetlands at Ruoergai adjacent to the First Great Bend of the Yellow River, Sichuan Province
Distinguished Visiting Professorship at the Chinese Academy of Sciences. All authors thank anonymous reviewers for their constructive comments on their papers. Helpful review comments assisted the completion of this editorial comment.

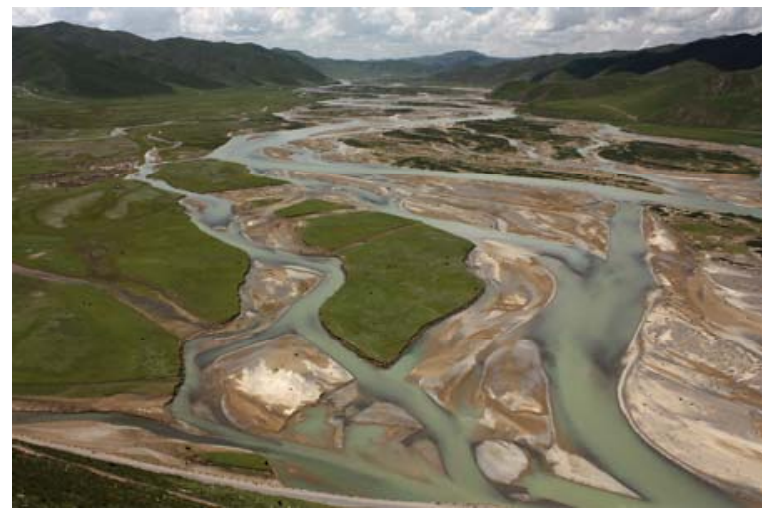

b) Braided-anabranching section of the Upper Yellow River immediately upstream of Dari

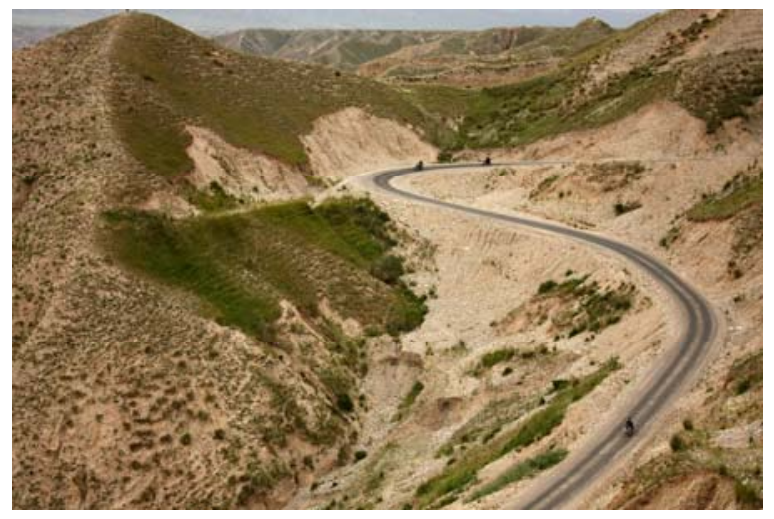

d) Hillslope failures associated with rapid infrastructure development in the Yellow River Source Zone

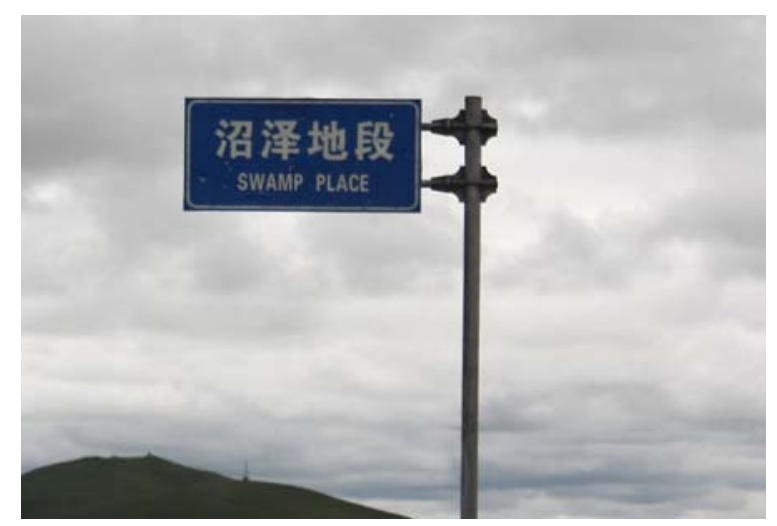

f) Swamp place at Ruoergai

Figure 1 Landscapes and riverscapes of the Yellow River Source Zone. Photographs provided by Brendon Blue (a) and Tami Nicoll (b-f). (To be continued) 


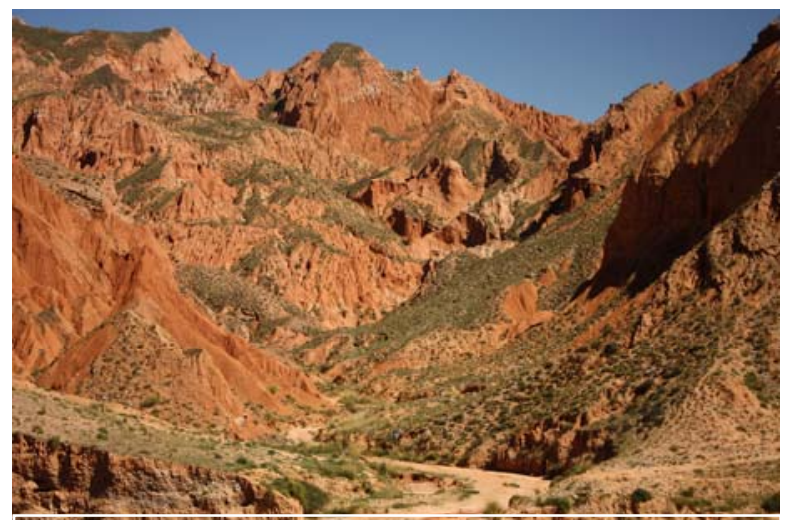

g) Dissected (highly connected) landscapes in Garang Catchment, an incised tributary of the Upper Yellow River near Guide

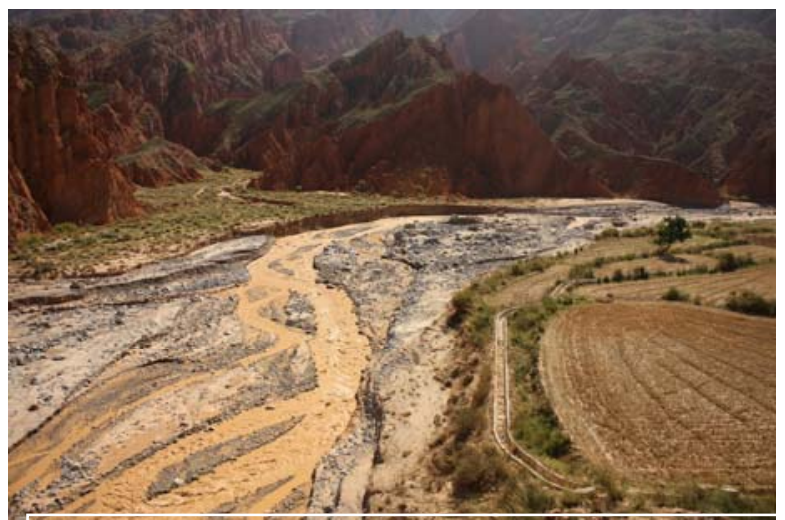

h) Stark variability in flow and sediment flux is evident in the highly connected landscapes of Garang Catchment, near Guide

Figure 1 Landscapes and riverscapes of the Yellow River Source Zone. Photographs provided by Brendon Biue (a) and Tami Nicoll (b-f). (Continued)

\section{References}

Aiken S, Brierley GJ (2013) Analysis of longitudinal profiles along the eastern margin of the Qinghai-Tibetan Plateau. Journal of Mountain Science 10 (4): 643657.DOI:10.1007/s11629-013-2814-2

Blue B, Brierley GJ, Yu GA (2013) Geodiversity in the Yellow River source zone. Journal of Geographical Sciences 23(5):775-792. DOI: $10.1007 / \mathrm{s} 11442-013-1044-4$.

Brierley GJ (2010) Environmental Futures: Research needs and strategies to protect and enhance environmental values in the Sanjiangyuan region. In: Brierley GJ, Li XL and Chen G (Editors). Landscape and Environmental Science and Management in the Sanjiangyuan Region. Qinghai People's Publishing House, Xining. pp. 228-238.

Brierley GJ, Fryirs KA, Cullum C, et al. (2013) Reading the landscape: Integrating the theory and practice of geomorphology to develop place-based understandings of river systems. Progress in Physical Geography. DOI: 10.1177/0309133313490007

Brierley GJ, Huang HQ (2013) Landscape relations to ecoenvironmental dynamics of the Sanjiangyuan. Journal of Geographical Sciences 23(5):771-774. DOI: 10.1007/s11442013-1043-5.

Gao J, Li XL, Brierley GJ, et al (2013a) Geomorphic-centered classification of wetlands on the Qinghai-Tibet Plateau, western China. Journal of Mountain Science 10 (4): 632-642. DOI:10.1007/s11629-013-2561-4

Gao J, Li XL, Cheung A, et al. (2013b) Degradation of wetlands on the Qinghai-Tibet Plateau: A comparison of the effectiveness of three indicators. Journal of Mountain Science 10 (4): DOI:10.1007/s11629-013-2562-3

Hu XS, Brierley GJ, Zhu HL, et al. (2013) An exploratory analysis of vegetation strategies to reduce shallow landslide activity on loess hillslopes, northeast Qinghai-Tibet Plateau, China. Journal of Mountain Science 10 (4): 668686.DOI:10.1007/s11629-013-2584-x

Li XL, Brierley G, Shi DJ, et al. (2012) Ecological protection and restoration in Sanjiangyuan National Nature Reserve, Qinghai Province, China. In: Higgitt D (Ed.), Perspectives on Environmental Management and Technology in Asian River
Basins. pp 93-120. Springer Briefs in Geography. DOI: 10.1007/978-94-007-2330-6_6.

Li XL, Perry GW, Brierley GJ, et al. (2013) Restoration prospects for Heitutan degraded grassland in the Sanjiangyuan. Journal of Mountain Science 10 (4): 687-698. DOI:10.1007/s11629-013-2557-0

Li XL, Gao J, Brierley G, et al. (2013) Rangeland degradation on the Qinghai-Tibet Plateau: Implications for rehabilitation. Land Degradation and Development 24:72-80. DOI: 10.1002/ldr.1108

Li ZW, Wang ZY, Pan B, et al. (2013) Analysis of controls upon channel planform at the First Great Bend of the Upper Yellow River, Qinghai-Tibetan plateau. Journal of Geographical Sciences 23(5): 833-848. DOI: 10.1007/s11442-013-1047-1.

Liu G, Chen Y, He HR (2012) China's environmental challenges going rural and west. Environment and Planning A. 44:16571660. DOI: $10.1068 / \mathrm{a} 45162$

Miehe G, Miehe S, Kaiser K, et al. (2009) How old is pastoralism in Tibet? An ecological approach to the making of a Tibetan landscape. Palaeogeography, Palaeoclimatology, Palaeoecology 276: 130-147. DOI: 10.1016/j.palaeo.2009.03.005

Nicoll T, Brierley G, Yu G (2013) A broad overview of landscape diversity of the upper Yellow River. Journal of Geographical Sciences, 23(5):793-816. DOI: 10.1007/s11442-013-1045-3.

Pietz D, Giordano M (2009) Managing the Yellow River: Continuity and Change. In: Molle F and Wester P (Eds). River Basin Trajectories: Societies, Environments and Development. CAB International, Wallingford, UK. pp 99-122.

Shapiro J (2012) China's Environmental Challenges. China Today, Polity Press, Cambridge.

Wang HJ, Yang ZS, Saito Y, et al. (2007) Stepwise decreases of the Huanghe (Yellow River) sediment load (1950-2005): Impacts of climate change and human activities. Global and Planetary Change, 57:331-354. DOI: 10.1016/j.gloplacha. 2007.01.003

Yu GA, Liu L, Li ZW, et al. (2013) Fluvial diversity in relation to valley settings in the source region of the Yangtze and Yellow Rivers. Journal of Geographical Sciences, 23(5):817-832. DOI: 10.1007/s11442-013-1046-2 